\title{
Maketu's Execution and the Extension of British Sovereignty in New Zealand
}

The execution of a minor chief in 1842 in Auckland Prison for the crime of murder would normally be of little significance in the evolution of a nation's statehood, unless it triggered some form or rebellion or even revolution. The history of colonial rule in the British Empire in the nineteenth century contains many examples of murderers receiving capital punishment for their crime. However, the constitutional significance of the Governor's determination to execute the criminal was of substantial, principally because it signified the Crown's willingness - at this relatively early stage in Crown Colony Government in New Zealand - to extend its jurisdiction so that British law would apply to Maori communities. Too often, it has been taken for granted that the Treaty of Waitangi asserted (initially in principle and gradually in practice) British sovereignty over Maori as well as Europeans in the country. However, what the Maketu example illustrates is that the limits of British sovereignty in New Zealand prior to 1842 were confined exclusively to the non-Maori population, as had been the expectation of the Colonial Office in the two years leading up to the conclusion of the Treaty.

\section{Background to the Murder}

Within a matter of months of the first signatures being inscribed on the Treaty of Waitangi, Hobson was on the lookout for a new capital for the country. ${ }^{1}$ The de facto capital at Russell was a ramshackle settlement that was unsuitable for a rapidly expanding settler population, and which was still

Professor Paul Moon is Professor of History at Te Ara Poutama, the Faculty of Maori Development at AUT University, and a Fellow fof the Royal Historical Society, University College, London. 
marred by its reputation as the 'hellhole of the Pacific'. ${ }^{2}$ In late 1840, Hobson made plans to shift the fledgling seat of government to Auckland, around 180 kilometres south of Russell. In the wake of this move, there was an exodus of settlers from the Bay of Islands to the new capital, although the region was not completely drained of its European presence. Most of those settlers who had established farms in the Bay of Islands area found that there were few buyers for their land, and so unable to afford to move to a new location, they had little option but to stay put and make the best of their circumstances.

One of these farming families was the Robertons. John Roberton had been a sailor, but had decided to change career, and in September 1839 purchased the island of Motuarohia in the Bay of Islands. The island covered an area of around 66 hectares, and was about one and a half kilometres from the mainland. ${ }^{3}$ The island was purchased from a consortium of chiefs, comprising Wharerahi, Moko, and Rewa, for £213, paid with a combination of cash and goods. ${ }^{4}$

Using nearby boulders, Roberton and his wife built the foundations of a small wooden house on a piece of flat land between the beach and the hills on the south-eastern side of the island. They commenced farming, and their son was soon joined by a daughter. Prospects for the young family were shattered, though, when Roberton died in 1840. He had been sailing 'merely for his own amusement' as his wife put it, in a new boat that a local builder had made, when a gust of wind capsized the vessel, and Roberton and the other person on board drowned. 5

John's wife, Elizabeth, was now widowed, with two small children and a farm that still had $£ 100$ owing on it. It might have been best for her to sell the farm, and take her children and whatever profits remained back to Britain, except that the colonial government was in the slow process of investigating all land purchases that had occurred prior to 1840 , which had the effect of freezing any land transactions in the interim. 
By the end of the year, the surrounding area was slowly sinking into an economic slump as Auckland replaced Russell as the country's main port and trading centre, and to make matters worse, the house was not finished, and Elizabeth described her and her children living in an inhospitable island in a cannibal country'. ${ }^{6}$ Elizabeth had no option but to try to make the best out of a bad situation. She had the aid of one servant (whom she struggled to pay), and barely enough livestock, but from this impoverished situation, she began to try to grind out a living from the farm.

In Elizabeth's mind, she owned the island as her husband had paid for it at a price agreed to by the vendors. However, as John had been the actual purchaser, and as John was now dead, traditional Maori custom dictated that the land be returned to its former owners. During 1841, hints, accusations, and threats were directed against Elizabeth by some Maori who were becoming increasingly militant in their insistence that the island be 'returned' to them. Ironically, the vendors themselves, who according to traditional practices would have been the ones to make such demands, did not do so, and appear to have accepted that the land they sold was now permanently in possession of the Robertons.

Elizabeth's anxiety was hardly eased by this technicality, so on 11 November 1841, she attended a hearing in Russell held by the Land Commissioner to investigate her claim to the island. The Land Commission had been established on the principle, as Hobson had explained it, that Maori 'never were in a condition to treat with Europeans for the sale of their lands, any more than a minor w[oul]d be who knows not the consequences of his own Acts'. ${ }^{7}$ The New South Wales administration agreed, with Gipps having introduced the New Zealand Land Bill to the New South Wales Legislative Council in July 1840, which was based on the principle that that the uncivilized inhabitants of any country have but a qualified dominion over it, or a right of occupancy only; and that, until they establish among themselves a settled form of government, 
and subjugate the ground to their own uses, by the cultivation of it, they cannot grant to individuals, not of their own tribe, any portion of it, for the simple reason, that they have not themselves any property in it'. 8

Elizabeth was hardly an exception in turning to the Land Commission to clarify her ownership. As William Swainson, the colony's Attorney-General, noted, 'At that time nearly the whole European population of the North Island were claimants of land alleged to have been purchased from the natives before the proclamation of the Queen's authority: the number of claims, in addition to the gigantic claims of the New Zealand Company, amounted to upwards of twelve hundred; and, in extent, they varied from a single rood to more than a million and a quarter of acres. Three of these claims exceeded a million of acres each; three of them comprised more than half a million of acres each, three others exceeded a quarter of a million of acres, and upwards of thirty of the claims comprised more than twenty thousand acres each. For some of these claims, the claimants had nothing to show but the ornamental scrawl or signature of one or more'. 9

The result of the hearing into Elizabeth's purchase was in her favour. The deed of purchase for Motuarohia was examined by the Commissioner, as was the will of John Roberton, in which the island was left to his wife. Moreover, Wharerahi, and Rewa - as the original vendors - both attended the hearing and attested to the fact that they signed the deed of sale with full understanding of its provisions, and that they had entertained no expectation of the island reverting to their ownership if John Roberton died. 10 The matter now seemed settled, and Elizabeth continued to salvage some sort of business from the struggling farm, safe in the knowledge that there was no chance that the land on which it lay would be pulled away from her by the Crown.

To help with work on the farm, Elizabeth enlisted the help of another settler, Thomas Bull (aged probably in his midthirties), and a short time afterwards, got additional assistance 
from 'a remarkably powerful'11 local 16-year-old named Maketu Wharetotara - the son of Ruhe, a minor chief from Waimate. The missionary George Clarke junior was suspicious of this latter addition to the island. 'There was madness in Maketu's family of a homicidal character', he later wrote. 'His brother and sister were both deranged, his aunt strangled herself in a paroxysm of rage, and his father Ruhe was subject to fits of frenzy, that made it dangerous for his best friends to go near him'. ${ }^{12}$ This assessment was written with the benefit of hindsight, though. There are no records of any warning being given to Elizabeth Roberton at the time when she hired the youth.

The complement of people on the farm was completed with the arrival of the three-year-old Isabella Brind, who was described five years later as 'the natural daughter of a Captain Brind, by a native woman - the daughter of Rewa, the head of the Ngapuhis, who principally inhabit Kororarika [sic]'. ${ }^{13}$ It is most probable that this addition to Elizabeth's family was made to earn favour with the Maori community closest to her farm.

Bull and Maketu possessed characters that were inflamed almost every time they came into contact with each other. Bull allegedly provoked Maketu on several occasions, ${ }^{14}$ and threatened the latter that 'he should have little or no food unless he worked better for Mrs. Roberton'.15 Bull threatened Maketu's source of employment, and belittled his mana as the son of a chief. In return, Maketu became sullen, which Bull mistook for laziness, ${ }^{16}$ thus exacerbating the ill-will between them.

Maketu's mind turned to justice - of a form he envisaged anyway. If his job was in jeopardy, and his status being demeaned, then utu, or revenge, had to be exacted. So on the evening of Saturday 30 November, Maketu grabbed an axe, crept up to where Bull lay sleeping, and split his head open. It was a gesture that would possibly have found some 
acceptance in traditional Maori communities, but that to European eyes was an outrage.

A near-contemporary account neatly laid out the sequence of events which occurred next: 'Mrs. Roberton having accidentally happened to come upon him [Maketu] when in the act of doing so, he judged it advisable to despatch her also with the same instrument, and then the two female children. Mrs. Roberton's son seeing what was going on, fled to a mountain close by, but the monster overtook him, and threw him headlong over the rock, two hundred feet high, so that he was literally dashed to pieces'. ${ }^{17}$

The press was more indignant in its reporting of the murders. One journalist wrote in graphic terms of how Elizabeth's body was 'horribly mangled and mutilated', Bull had been 'decapitated', and 'the remains of a child were found burnt in the ashes of a house'. The result was a 'most shocking and inhuman atrocity'.18

Yet, Maketu was not at first a suspect. He had fled the scene, perhaps acknowledging that his transgression was bound to reap repercussions, and the authorities in Russell apprehended three Europeans whom they initially suspected of the crime. ${ }^{19}$ Initially, as one Victorian historian noted, 'No human being could now bear witness against Maketu; he fired the house where the murdered lay, [and] paddled in a canoe to his father's village'. ${ }^{20}$ Once there, though, he confessed to his actions, and reports of his guilt spread swiftly throughout the region.

\section{Initial Response}

When the news of the killings on the island reached Russell, two local merchants - Mr. Wilson and Mr. Spicer - sent messages to the three British naval ships which happened to be in the Bay at that time. ${ }^{21}$ They also sent an urgent note to the town's police magistrate, but in the panic, it was misaddressed, and ended up on one of the naval ships. The 
captains on the vessels agreed not to act unless they were formally warranted to do so by the magistrate, so sensing that valuable time could be lost in gaining the necessary approval, the two merchants engaged a small boat with a crew of five and headed towards the island.

As they approached the shore, a group of Maori who had moved onto the island threatened to kill them, but these seasoned residents were not so easily put off by such bluffing, and without flinching, demanded that Maketu be handed over to them. A settler recorded the astonishing course of events which followed: "The merchants then spoke of the enormity of the crime which the prisoner had been guilty of; and many of the chiefs said it was very wicked to do such a thing as murder a woman. The merchants, finding there was no chance of obtaining the prisoner by fair means, went amongst the whole of the natives, 1500 in number, although the latter threatened to kill them with their tomahawks. But they, being assured from their knowledge of native manners and customs that this threat would not be put into execution, did not hesitate to seize the prisoner, and, with the assistance of their crew, put him into their boat, the natives all the while looking on with astonishment, but afraid to attack the Europeans, as they knew the prisoner had been guilty of murder'. ${ }^{22}$ However, a further confrontation forced Spicer and Wilson to leave the island late that evening without Maketu. ${ }^{23}$

It was none-the-less a brave gesture, and one made all the more remarkable because, on the face of it, it was unnecessary. At Russell, there were police constables as well as a detachment of troops from the $81^{\text {st }}$ Regiment, and the crews of three naval ships. ${ }^{24}$ However, the magistrate was adamant that troops would not be used, believing that any show of force on behalf of the British would prompt aggression from those Maori protecting Maketu. He was prepared to wait for official permission from Hobson before committing troops, and so the cause of tension in the region - the failure by the British to apprehend Maketu - remained. 
Henry Williams' wife, Maryanne, recorded on 23 November 1841 how the situation was revealed to her family, and the sense of apprehension that the event instilled in them. 'Just as we were going to bed', she wrote, 'a note brought from $\mathrm{Mr}$. Busby, mentioning that the murderer was discovered to be a son or brother of Ruhe; that upwards of three hundred natives were assembled at Motu Apohia, generally called Robertson's island, and refused to give the murderer up; that one of Rewa's sons was sitting with him...altogether, it was more alarming than anything he [Busby] had known in New Zealand; that Mr. King thinks the natives ripe for an outbreak, and that Mr. Mair had intimations of the same nature. That Mr. Beckham, the police magistrate, was to go to Kerikeri for Mr. Clarke, and to write to Auckland for all the disposable force. We shuddered as we talked over it'. 25

There was a fear among the local European community that capturing and arresting the suspect could lead to a sudden eruption in violence in the region, with vulnerable settlers bearing the brunt of any conflagration. The local magistrate initially refused to seize the suspect, fearing that the consequences would outweigh the merits in apprehending a criminal. Eventually, though, Henry Williams applied the pressure of diplomacy to yield the desired result, but it was a delicate and risky process, as Williams wrote in April 1842: 'The disturbance arising from the arrest of Maketu was happily suppressed, but I do not hesitate to say, that had not the grandchild of Rewa been one of the victims, thus bringing all the Ngapuhi tribes as auxiliaries to the Europeans in the event of war, the result would have been far otherwise. The assertion of the Colonial Secretary, that the natives never did entertain an opinion of distrust, as far as regards the Government, required more reflection than perhaps was given to it; for the fact is too palpable to be refuted. I must say that I do not know a chief who has not expressed his "distrust" in the Europeans generally; and it has required all my energies and influence, in common with other Missionaries, amongst the natives, to set 
their minds at rest upon these subjects'. ${ }^{26}$ The suspect was finally delivered into the hands of the police magistrate by his own community; 'partly from a sense of justice, and partly from terror of the relations of the murdered half-caste infant, a powerful tribe in the Bay of Islands', as a writer in the 1850s put it. ${ }^{27}$ Missionary pleading also played a major part in the crisis reaching a peaceful resolution.

As the weeks passed, however, the peace in Northland in the wake of Maketu's capture looked increasingly brittle. The threat that British law would apply to Maori was at the heart of the mounting fury of some Maori in the region. Henry Williams reported that "The Missionaries were threatened, it having been stated that Mr. Clarke and I had taken Maketu as a prisoner on board the Government brig. A large party had been met on the road, fully equipped for mischief, and threatening the Mission. As soon as this intelligence was received at Paihia, I paid an especial visit to the chiefs around the Bay, who all regarded the affair as most serious, and advised me to call a general meeting for the following Thursday, to be held at Paihia, as no time was to be lost'. The meeting was held, but to start off with, there was 'much angry language was used by Pomare, Heke, and others, against the Government and the pakeha'. However, as the afternoon drew on, the 'angry feeling began to subside, and the conduct of the opponents to order and justice condemned by the welldisposed. At sunset, all dispersed quietly to their places. Ruhe, the father of the culprit, fully approved that the law should be carried out, though months passed before quietness was fully established'.28

\section{The Beginnings of the Extension of British Jurisdiction}

The result was a resolution signed by around twenty chiefs 29 on 16 December 1841. Here, for the first time, was a document endorsed by a number of tribal leaders, supporting the extension of British (criminal) law to their communities, at 
least in the case of capital offences: 'Sir, Maketu's work is his alone, his own; we have nothing to say for him. That man is with you; leave him there. Do not bring him back here to us, lest there be a disturbance: leave him there. Governor, do not listen to the reports that have flown about in the wind....Sir, Governor, let your regard be great for us, the children of the Queen Victoria, the Queen of England, of Europe also. Now, this is the word of the book: "Love one another." This is a good word. Shew us the greatness of your regard to us and our children, and we shall all turn without one exception to Victoria to be her children. But if not, what shall we do? Governor, here we are sitting in ignorance; we have no thoughts; you are our parent'. 30

The murder of Europeans by Maori was an extremely rare occurrence at this time, but in the minds of settlers, as the country had recently become a British colony, there was an expectation that British justice would somehow to the incident. ${ }^{31}$ The emphasis, though, was on 'somehow'. Although British rule had been formally established in the colony through the provisions of the Treaty of Waitangi, in practice, Maori sovereignty still prevailed over the majority of the country's territory. And to complicate matters further, official policy on the jurisdiction of British law in New Zealand was still far from clear.

During 1839, when the final touches were being put on the British policy to annex New Zealand, consideration turned to the issue of over whom would British sovereignty would apply. The decision boiled down to two options: either the sovereignty of the Crown would blanket everyone in the country, or it would apply just to British subjects living there. The Colonial Office went for the latter (cheaper) option. Glenelg wanted British rule to prevail only in 'certain well-defined portions of the country....where the British are already settled'. ${ }^{32}$ In March 1839, Sir James Stephen, the sagacious permanent head of the Colonial Office, expressed a preference for the establishment of a ruling body in New Zealand which would 
govern 'the Anglo Saxon Race'. ${ }^{33}$ By June 1839, British policy had firmed, with officials desiring the appointment of a consul in New Zealand who would exercise 'some competent control over British subjects in the New Zealand Islands'34 - a policy endorsed by the British Treasury, which agreed to find the annexation of New Zealand on this basis. ${ }^{35}$ Hobson's decision to put Maketu on trial stretched the elasticity of Colonial Office policy to an extreme degree, making the law that was supposed to govern settlers now apply to the country's Maori population.

On 1 March 1842, Maketu made his appearance in the Supreme Court in Auckland. He was found guilty and executed on 7 March. The gossip in Auckland was that Maketu's execution would take place in the Bay of Islands - as close as possible to the scene of his murders. However, Hobson and his Executive Council immediately sensed that this would be one provocation too far and prudently decided that the convicted youth would be executed in Auckland, where British authority was at its strongest.

At first light on the $7^{\text {th }}$, carpenters and smiths worked on erecting the gallows. At the same time, an apparently deeply penitent Maketu requested the presence of a minister, and the Reverend Churton attended to him, baptising the prisoner under the name William King. Then, at midday, Maketu dressed in a blue blanket - was brought from his cell. He exhibited the peculiarly dignified demeanour and appearance for which the native chiefs are so peculiarly distinguished', as one observer wrote. ${ }^{36}$ The prison bell tolled, and Maketu was led to the scaffold, which was surrounded by a large military guard, in case there was any last-minute attempt by a sympathetic group of Maori to rescue the prisoner. As it turned out, however, there were few Maori present, (although around a thousand Europeans turned up to witness the spectacle). A few minutes after 12 noon, Maketu was cast off, the noose snapped his neck, and he died 'almost instantly'. ${ }^{37}$ 
It was the ultimate penalty able to be exacted against a criminal under British law, and the fact that it was a Maori who was sentenced, convicted, and executed for a crime set in motion the extension of British jurisdiction throughout the country, but more importantly, its application to Maori, who made up the vast majority of New Zealand's population at the time, and who, prior to the Maketu case, were considered by almost everyone to exist beyond the reach of British law.

In 1842, Swainson wrote to the Colonial Office, querying this usurpation of Maori sovereignty, which, in his legal opinion, went beyond the provisions of the Treaty of Waitangi. Stephen wrote a minute on the matter in 1843, which concluded 'Mr Swainson may think this is unjust or impolitic or inconsistent with former Acts, but still it is done'. ${ }^{38}$ As far as Britain was concerned, the decision to try and convict a Maori on a serious charge was a major evolutionary step in the jurisprudential history of the colony.

Maketu's capture and delivery to the colonial authorities in Auckland was the most likely outcome of the murders he committed against settlers. The credibility of Hobson's government would possibly have been questioned by colonial officials in London, and certainly by the colony's settlers if he had failed to apprehend the suspect. And once in custody, the penalty was never really in question. However, what made this extension of British law into Maori communities possible in the manner in which it happened was the 16 December 1841 resolution which the twenty chiefs signed. At the very least, this gave Hobson the impression (if not the guarantee) that he would not have to wage war against Maori to secure the right to punish a Maori murderer.

More broadly, the chiefs' resolution can be seen as an early gesture of the partnership which had been established by the Treaty of Waitangi. Rather than the Governor dictating the terms of British rule and the extension of the sovereignty mentioned in the Treaty, the reach of British rule, at this stage only for capital offences, and only $\mathrm{n}$ the territories over which 
those twenty chiefs presided, took place by mutual agreement. The subsequent three years of Maori-Crown relations were more fractious in some areas, and to a degree, this degraded relationship reflects the failure of both parties to the Treaty, but especially the Crown, to pursue further opportunities for such partnership.

\section{Notes}

1 J. Horsman, The Coming of the Pakeha to Auckland Province, Wellington, 1971, p. 71; R. Wolfe, Auckland: A Pictorial History, Auckland, 2002, p. 12; Colonial Gazette, August 1842, p. 2.

2 R. Wolfe, Hell-Hole of the Pacific, Auckland, 2005; M. 'Umi Perkins, Mana/'Ike: Maori and Native Hawaiian Education and Self-Determination, Honolulu, 2004, p. 8.

3 Department of Statistics, The University of Auckland, Roberton Island / Motuarohia, Auckland, 2012, p. 1.

4 M. Lennard, Motuarohia: An Island in the Bay of Islands, Sometime Known as Roberton's Island, Auckland, 1959, p. 14.

5 E. Roberton to W. Roberton, 1840, in M. Lennard, p. 15.

6 Op. cit.

7 Hobson to Gipps, 16 January 1840, in D. Moore, B. Rigby, and M. Russell, Rangahaua Whanui National Theme A: Old Land Claims, Wellington, 1997, p. 14

$8 \quad$ G. Gipps speech, 9 July 1840, in Great Britain Parliamentary Papers, 1841, vol. 311, London, 1841, pp. 63-64. W. Swainson, New Zealand and its Colonization, London, 1859, p. 90.

10 For details of the conflicting land systems, see S. Banner, 'Two Properties, One Land: Law and Space in Nineteenth-Century New Zealand', in Law and Social Inquiry, vol. 24, 1999, pp. 807-852.

11 J. C. Ross, A Voyage of Discovery and Research in the Southern and Antarctic Regions, vol. 2, London, 1847, p. 127.

12 G. Clarke, Notes on Early Life in New Zealand, Hobart, 1903, p. 41.

13 A. Marjoribanks, Travels in New Zealand with a Map of the Country, London, 1846, p. 170.

14 M. Lennard, p. 18.

15 New Zealand Gazette and Wellington Spectator, 8 December 1841, p. 2.

16 M. Lennard, p. 18.

17 A. Marjoribanks, p. 171.

18 New Zealand Gazette and Wellington Spectator, 8 December 1841, p. 2.

19 Op. cit.

20 A. S. Thomson, The Story of New Zealand: Past and Present, Savage and Civilized, vol. 2, London, 1859, p. 51.

21 The ships were HMS Erebus, HMS Terror, and HMS Favorite. 
22 W. Brodie, Remarks on the Past and Present State of New Zealand: Its Government, Capabilities and Prospects, London, 1845, pp. 24-5.

23 M. Lennard, p. 20.

24 W. Brodie, Remarks on the Past and Present State of New Zealand: Its Government, Capabilities and Prospects, p. 25.

25 M. Williams, in H. Carleton, The Life of Henry Williams: Archdeacon of Waimate, vol. 2, p. 38.

26 H. Williams to J. Busby, 20 April 1842, in H. Carleton, The Life of Henry Williams: Archdeacon of Waimate, vol. 1, Wellington, 1948, appendix 2, p. xxii.

27 A. S. Thomson, vol. 2, p. 51.

$28 \mathrm{H}$. Williams, in H. Carleton, The Life of Henry Williams: Archdeacon of Waimate, vol. 2, pp. 37-8.

29 This number includes signatories to a subsequent letter which was almost identical to this resolution.

30 The Resolutions agreed upon by the Chiefs of Ngapuhi, assembled at Paihia on the 16th December, 1841, in ibid., p. 43.

31 A. S. Thomson, vol. 2, p. 51.

32 Glenelg, CO minute, 12 February 1839, in E. Sweetman, The Unsigned New Zealand Treaty, Melbourne, 1939, p. 6.

33 J. Stephen to H. Labouchere, 15 March 1839, in W. D. McIntyre and W. J. Gardiner (eds.), Speeches and Documents on New Zealand History, Oxford, 1971, pp. 8-10.

34 G. J. Pennington to J. Stephen, 22 June 1839, in Great Britain Parliamentary Papers 1840, vol. 33, London, 1840, p. 33.

35 Treasury Minute, 19 July 1839, in Great Britain Parliamentary Papers 1840, vol. 33, London, 1840, pp. 34-5; P. Moon, Te Ara Ki Te Tiriti, The Path to the Treaty of Waitangi, pp. 99-102.

36 New Zealand Gazette and Wellington Spectator, 26 March 1842, p. 2.

37 Op. cit.; G. W. Rusden, p. 289.

38 J. Stephen, minute, c. April 1843, in E. Sweetman, pp. 190-1. 